\title{
IL-12 p40 prevents the development of chronic enterocolitis in IL-10-deficient mice
}

\author{
Manabu Shiraki ${ }^{1}$, Hiroyuki Aihara ${ }^{1}$, Yoshitaka Kinouchi ${ }^{1}$, Seiichi Takahashi ${ }^{1}$, Motoji Oki ${ }^{1}$, \\ Mitsunori Noguchi ${ }^{2}$, Kazuma Takahashi ${ }^{3}$, Jun-ichi Miyazaki ${ }^{4}$ and Tooru Shimosegawa ${ }^{1}$ \\ ${ }^{1}$ Division of Gastroenterology, Tohoku University Graduate School of Medicine, Sendai, Japan; ${ }^{2}$ Sendai \\ Shakaihoken Hospital, Sendai, Japan; ${ }^{3}$ Division of Molecular Metabolism and Diabetes, Tohoku University \\ Graduate School of Medicine, Sendai, Japan and ${ }^{4}$ Division of Stem Cell Regulation Research (G6), Osaka \\ University Graduate School of Medicine, Osaka, Japan
}

\begin{abstract}
T-helper-1 (Th1) cytokines play an important role in Crohn's disease, and interleukin-12 (IL-12), which is composed of two subunits, p40 and p35, drives Th1 differentiation. In previous reports, IL-12 p40 was shown to prevent IL-12 from binding to the receptor. We demonstrate here the effect of IL-12 p40 overexpression in intestinal epithelia on enterocolitis mediated by Th1 cells in IL-10-deficient (IL-10-1-) mice on a C57BL/6J

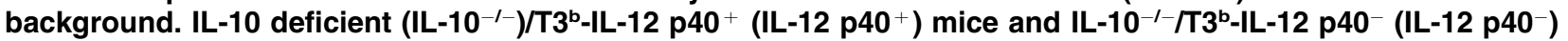

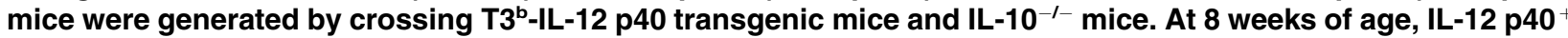
mice did not show any clinical manifestations of colitis. The colon length of IL-12 p40- mice became shorter than that of IL-12 $\mathrm{p} \mathrm{O}^{+}$mice. The histological score of IL-12 $\mathrm{p} 40^{+}$mice was lower. Interferon-gamma (IFN- $\gamma$ ) production was suppressed in both the mesenteric lymph node cell culture and colon tissue culture of IL-12 $\mathrm{p}^{+} 0^{+}$mice. There was no significant difference in IL-4 production and tumor necrosis factor-alpha (TNF- $\alpha$ ) production between the two groups. These results show that overexpression of IL-12 p40 in intestinal epithelia prevents enterocolitis in IL-10 ${ }^{-1-}$ mice by suppressing IFN- $\gamma$ production, and suggest a potential clinical application of IL-12 p40 for Crohn's disease. Furthermore, these results also suggest that local gene transduction in the intestinal epithelium may be a potent therapeutic approach for Crohn's disease.

Laboratory Investigation (2004) 84, 1491-1500, advance online publication, 27 September 2004; doi:10.1038/labinvest.3700175
\end{abstract}

Keywords: IL-12 p40; IL-10-deficient-mice; Th1 cytokine

Inflammatory bowel disease (IBD), which includes both Crohn's disease and ulcerative colitis, is an idiopathic chronic disease. ${ }^{1}$ The precise pathogenesis of IBD is still unclear, but T-helper-1 (Th1) cytokines have been reported to play a pivotal role in the development of Crohn's disease. ${ }^{2,3}$ Recently, various mice models of intestinal inflammation mediated by a Th1 response have been established. These mice models, including interleukin (IL)-2), ${ }^{4,5}$ IL-10, and Stat $3^{6}$-deficient mice, IL-7 transgenic mice, ${ }^{7}$ Tnf ${ }^{\triangle A R E}$ mice, ${ }^{8,9}$ senescence accelerated mice P1/Yit strain, ${ }^{10,11}$ 2,4,6-trinitrobenzenesulfonic acid (TNBS)-treated mice, ${ }^{12}$ and $\mathrm{CD} 4^{+} \mathrm{CD} 45 \mathrm{RB}^{\text {high }} \mathrm{T}$ cell transferred SCID mice, ${ }^{13,14}$ have provided new insight concerning the intestinal inflammation of Crohn's disease and its pathogenesis. The methods

Correspondence: Dr M Shiraki, MD, Division of Gastroenterology, Tohoku University Graduate School of Medicine, 1-1 Seiryo, Aoba, Sendai 980-8574, Japan.

E-mail: sankara@qf6.so-net.ne.jp

Received 9 June 2004; revised 2 August 2004; accepted 3 August 2004; published online 27 September 2004 by which the inflammation is prevented in these models could lead to new cytokine therapies for Crohn's disease.

IL-12, which is a $70 \mathrm{kDa}$ heterodimeric cytokine composed of two disulfide-linked subunits, p40 and p35, is a key cytokine that drives naïve T cells to Th1 differentiation. ${ }^{15-17}$ In Crohn's disease, it has also been reported that the excessive expression of IL-12 produced predominantly by macrophages and dendritic cells promotes the Th1 response. ${ }^{18,19}$ Furthermore, IFN- $\gamma$ induced by IL-12 can promote the upregulation of IL-12 production. ${ }^{20}$ This cycle promotes the chronic intestinal inflammation of Crohn's disease. The prevention of this cycle, therefore, could be an effective therapy for Crohn's disease. Although several ways to prevent this cycle have been reported, we focused on IL-12 p40 in the present study. Because IL-12 p40, especially a homodimeric form of IL-12 p40, has affinity for the IL-12 receptor, prevents the binding of a heterodimeric form of IL-12, ${ }^{21,22}$ and is not a foreign protein in vivo, IL-12 p40 would not likely make an unwelcome antibody. 
We have used $T 3^{b}$ gene promotor to overexpress IL12 p40 in the intestine of mice. The $T 3^{b}$ gene encodes one of the thymic antigens, which are nonclassical major histocompatibility complex class I molecules, and in the C57BL/6 mouse strain it is expressed exclusively in the intestinal epithelium. ${ }^{23}$ Using the $T 3^{b}$ gene promoter thus enables us to verify whether the intestinal epithelium is the proper target of the gene therapy in mice with experimental transluminal colitis resembling Crohn's disease. We previously reported transgenic mice overexpressing IL-12 p40 in the epithelial cells of the small and large intestines, specifically under the control of the $T 3^{b}$ gene promoter. $^{24}$ There were no abnormalities in T3 ${ }^{\mathrm{b}}$-IL-12 p40 transgenic mice in a specific pathogen-free condition.

In this study, we generated double-mutant mice by crossing IL-10-deficient (IL-10 ${ }^{-/}$) mice, which develop spontaneous chronic colitis mediated by Th1 cells expressing $\mathrm{CD} 4,{ }^{25-28}$ and transgenic mice overexpressing IL-12 p40 to assess the therapeutic effects of IL12 p40 in $\mathrm{IL}-10^{-/-}$mice. We demonstrate that the overexpression of IL-12 p40 in the gastrointestinal tract can suppress the spontaneous chronic enterocolitis of IL- $10^{-/-}$mice, which suggests the potential of using IL-12 p40 as a therapy for Crohn's disease.

\section{Materials and methods}

\section{Mice}

The generation of $\mathrm{T} 3^{\mathrm{b}}$-IL-12 $\mathrm{p} 40$ transgenic mice on a C57BL/6J background has been previously described. ${ }^{24}$ IL-10 $0^{-1-}$ mice on a C57BL/6J background were purchased (The Jackson Laboratory, ME, USA). IL-10 $0^{-/-} / \mathrm{T}^{\mathrm{b}}-\mathrm{IL}-12 \mathrm{p} 40^{+}\left(\mathrm{IL}-12 \mathrm{p} 40^{+}\right)$mice and IL$10^{-I-} / \mathrm{T} 3^{\mathrm{b}}-\mathrm{IL}-12 \mathrm{p} 40^{-}\left(\mathrm{IL}-12 \mathrm{p} 40^{-}\right)$mice were generated by crossing $\mathrm{IL}-10^{-1-}$ mice and $\mathrm{T} 3^{\mathrm{b}}-\mathrm{IL}-12 \mathrm{p} 40$ transgenic mice. The genotyping of the mice was performed by PCR using tail DNA isolated by the sodium dodecyl sulfate-proteinase $\mathrm{K}$ method. All mice were maintained under specific pathogen-free conditions in the animal facility at Tohoku University Graduate School of Medicine. At weekly intervals, we inspected the mice for clinical symptoms such as diarrhea and anal prolapse from 3 weeks of age. The body weights of the mice were also measured. Animals were killed by cervical dislocation at 8 weeks of age. The length of the colon was measured for the assessment of morphologic change. The entire tissue sections of the colon were made for histological analysis and colon tissue culture. Mesenteric lymph node cells were also collected for cell culture. All mice received humane care in accordance with the law concerning the protection and control of animals in Japan.

\section{Histology}

The colon tissues were fixed in $10 \%$ formalin. Paraffin sections were then made and stained with hematoxylin and eosin. Histological analysis was performed in a blinded fashion by one pathologist. The tissue sections were divided into five regions: cecum, ascending, transverse, descending colon, and rectum. The evaluation of inflammation in the entire colon was performed by the summation of the scores for each region, which were graded semiquantitatively from 0 to $4 .{ }^{27,29}$ The grading represents the degree of severity of mucosal inflammation and epithelial cell hyperplasia as follows: 0, no signs of inflammation; 1 , very low level of leukocytic infiltration in the lamina propria with mild epithelial hyperplasia and without the depletion of goblet cells; 2, mild inflammatory cell infiltration in the lamina propria with mild epithelial hyperplasia and depletion of goblet cells; 3, inflammation involved the submucosa and crypt abscess were occasionally found. Moderate epithelial hyperplasia and depletion of goblet cells were also seen; 4, inflammation involved the submucosa, and was sometimes transluminal. Marked epithelial hyperplasia and elongated glands with few goblet cells were found.

\section{Immunohistochemistry}

Colon tissues were fixed in periodate-lysine- $4 \%$ paraformaldehyde overnight at $4{ }^{\circ} \mathrm{C}$ and then frozen in Optimal Cutting Temperature compound (Sakura Finetechnical Co., Ltd, Tokyo, Japan). Serial sections (6 $\mu \mathrm{m}$ thick) were cut with a cryostat and placed on 3-amino-propyltriethoxysilane-coated slides. Blocking was performed in Histofine blocking anti-goat serum (Nichirei Tokyo, Japan) for $12 \mathrm{~min}$ at room temperature. Samples were washed twice in phosphate-buffered saline (PBS) and then incubated overnight $4{ }^{\circ} \mathrm{C}$ with a rat anti-mouse IL-12 (p40/p70) monoclonal antibody, C15.6 (Pharmingen, San Diego, CA, USA), at a density of $2.5 \mu \mathrm{g} / \mathrm{ml}$ in PBS supplemented with $0.5 \%$ FBS and $0.05 \%$ sodium azide. These slides were washed three times in PBS. Endogenous peroxidase was quenched by incubating the samples in $0.3 \% \mathrm{H}_{2} \mathrm{O}_{2} /$ methanol for $12 \mathrm{~min}$ at room temperature. And then the slides were incubated for an hour at room temperature with secondary antibody, F(ab') fragments of anti-rat immunoglobulin coupled to horseradish peroxidase (Zymed, San Francisco, CA, USA) at a density of $0.025 \mu \mathrm{g} / \mathrm{ml}$ in PBS. Following subsequent washes in PBS, the color reaction was developed with diaminobenzidine. Slides were counterstained with hematoxylin.

\section{Mesenteric Lymph Node Cell Cultures}

Mesenteric lymph node cell cultures were performed in RPMI medium 1640 (Invitrogen, Carlsbad, CA, USA) supplemented with $10 \%$ FBS, $50 \mu \mathrm{M} \mathrm{2-}$ mercaptoethanol, $100 \mathrm{U} / \mathrm{ml}$ penicillin/streptomycin (Invitrogen, Carlsbad, CA, USA) and $10 \mu \mathrm{g} / \mathrm{ml}$ 
concanavalin A (conA) at $37^{\circ} \mathrm{C}$ in humidified $5 \%$ $\mathrm{CO}_{2}$ for $24 \mathrm{~h}$ using 24-well flat bottom plates (Becton Dickinson Labware, Franklin Lakes, NJ, USA). The density of the mesenteric lymph node cells was adjusted at $2 \times 10^{6}$ cells $/ \mathrm{ml}$. The supernatants of the mesenteric lymph node cell culture were collected for cytokine analysis.

\section{Cell Isolation and Cell Culture of Mesenteric CD4 ${ }^{+}$ T Cells}

Collected mesenteric lymph node cells were centrifuged for $7 \mathrm{~min}$ at 1400 rounds per minute, and $\mathrm{CD}^{+} \mathrm{T}$ cells were isolated from mesenteric lymph node cells by the MACS magnetic cell sorting system (Militenyi Biotech, Auburn, CA, USA) according to the manufacturer's protocols. The validity of cell isolation was verified by flow cytometry. In all, 96-well flat bottom plates (Becton Dickinson Labware, Franklin Lakes, NJ, USA) were coated with $10 \mu \mathrm{g} / \mathrm{ml}$ murine anti-CD3 $\varepsilon$ antibody (Pharmingen, San Diego, CA, USA) in PBS overnight at $4^{\circ} \mathrm{C}$. CD $4^{+} \mathrm{T}$ cells at $1 \times 10^{6}$ cells $/ \mathrm{ml}$ were then cultured in RPMI medium 1640 supplemented with $10 \%$ FBS, $50 \mu \mathrm{M}$ 2-mercaptoethanol, $100 \mathrm{U} / \mathrm{ml}$ penicillin/streptomycin, and $5 \mu \mathrm{g} / \mathrm{ml}$ soluble antiCD28 antibody (Pharmingen, San Diego, CA, USA) in the precoated wells for $24 \mathrm{~h}$. The supernatants of the isolated mesenteric CD4 ${ }^{+}$T-cell culture were collected for cytokine analysis.

\section{Colon Tissue Cultures}

Colon tissue biopsy specimens were obtained by the following method: ${ }^{30}$ The harvested colon tissue was cleared of fecal matter by flushing with PBS, split longitudinally, and six full-thickness colon biopsy specimens with a diameter of $3 \mathrm{~mm}$ were obtained from the distal and proximal colon using a dermal punch biopsy instrument (Kai Industries Co., Ltd, Seki, Japan). Each biopsy specimen was then transferred onto a stainless-steel mesh with the mucosal side up in a well of a 24-well tissue culture plate containing RPMI medium 1640 supplemented with 10\% FBS, $50 \mu \mathrm{M}$ 2-mercaptoethanol, $100 \mathrm{U} / \mathrm{ml}$ penicillin/streptomycin, and $10 \mu \mathrm{g} / \mathrm{ml}$ conA. The tissue was cultured for $24 \mathrm{~h}$ using the same method as for the mesenteric lymph node cell culture. The supernatants of the colon tissue culture were collected for cytokine analysis.

\section{Western Blot Analysis}

The harvested colon tissue was cultured as mentioned above, but the culture medium did not contain 2-mercaptoethanol. The culture supernatants were separated by the sodium dodecyl sulfate-polyacrylamide gel electrophoresis $(10 \%)$ under reducing or non-reducing conditions. The separated proteins were transferred to a $0.45 \mu \mathrm{m}$ nitrocellulose mem- brane (Bio-Rad, CA, USA). Transblots were incubated with a rat anti-mouse IL-12 (p40/p70) monoclonal antibody, C17.8 (Pharmingen, San Diego, CA, USA) and then incubated for an hour with secondary antibody, F(ab') fragments of anti-rat immunoglobulin coupled to horseradish peroxidase (Zymed, San Francisco, CA, USA). The antibody-reactive proteins were visualized using ECL Western Blotting Detection Reagents (Amersham Bioscience Buckinghamshire, England) according to the manufacturer's protocol.

\section{Cytokine Analysis}

To detect the cytokine production of IFN- $\gamma$, IL-12, IL-4, and TNF- $\alpha$ by the mesenteric lymph node cells, by the CD4 ${ }^{+} \mathrm{T}$ cells and colon tissues, ELISA was performed using a mouse ELISA kit (ENDOGEN, Woburn, MA, USA) according to the manufacturer's protocols.

\section{Statistical Analysis}

All data are expressed as the mean \pm standard deviation. Statistical difference was assessed using Mann-Whitney test. The level of significance was set at $P<0.05$.

\section{Results}

\section{Detection of Overexpression of IL-12 p40 in IL-12 $\mathrm{p40}^{+}$mice}

We confirmed the overexpression of IL-12 p40 in IL$12 \mathrm{p} 40^{+}$mice. Immunohistochemical analysis of the colon tissues demonstrated that the epithelial cells of the colon in IL-12 $\mathrm{p}^{+} 0^{+}$mice were strongly stained by anti-IL-12 monoclonal antibody (Figure 1a). Close examination of the sections revealed that the IL-12 p40 expression was mainly by mature absorptive cells facing to the lumen and by lymphocytes (Figure 1b). The epithelial cells of the colon of IL-12 ${\mathrm{p} 40^{-}}^{-}$mice were not stained (Figure 1c). However, lymphocytes found in the colonic mucosa were stained in a granular pattern (Figure 1d). Next we performed Western blot analysis to determine what form of IL-12 p40 was present. Western blot analysis showed two bands around 80 and $40 \mathrm{kDa}$ in the supernatant of the colon tissue culture of IL-12 $\mathrm{p}^{+} 0^{+}$mice under a nonreducing condition (Figure 2). The position of the upper band was the same as that of the control recombinant IL-12 p40 homodimer, which is the upper one. Moreover, the bands of the IL-12 $\mathrm{p} 40^{+}$mice, control recombinant IL-12 p40 homodimer, and recombinant IL-12 heterodimer around 80 and $70 \mathrm{kDa}$ shifted downward to around $40 \mathrm{kDa}$ under a reducing condition. One very weak band of the IL-12 $\mathrm{p}^{-} 0^{-}$mice could be seen around $40 \mathrm{kDa}$. We also confirmed that the overexpression of IL-12 p40 was found not in lymph node cells but mainly in the colonic mucosa using ELISA. 

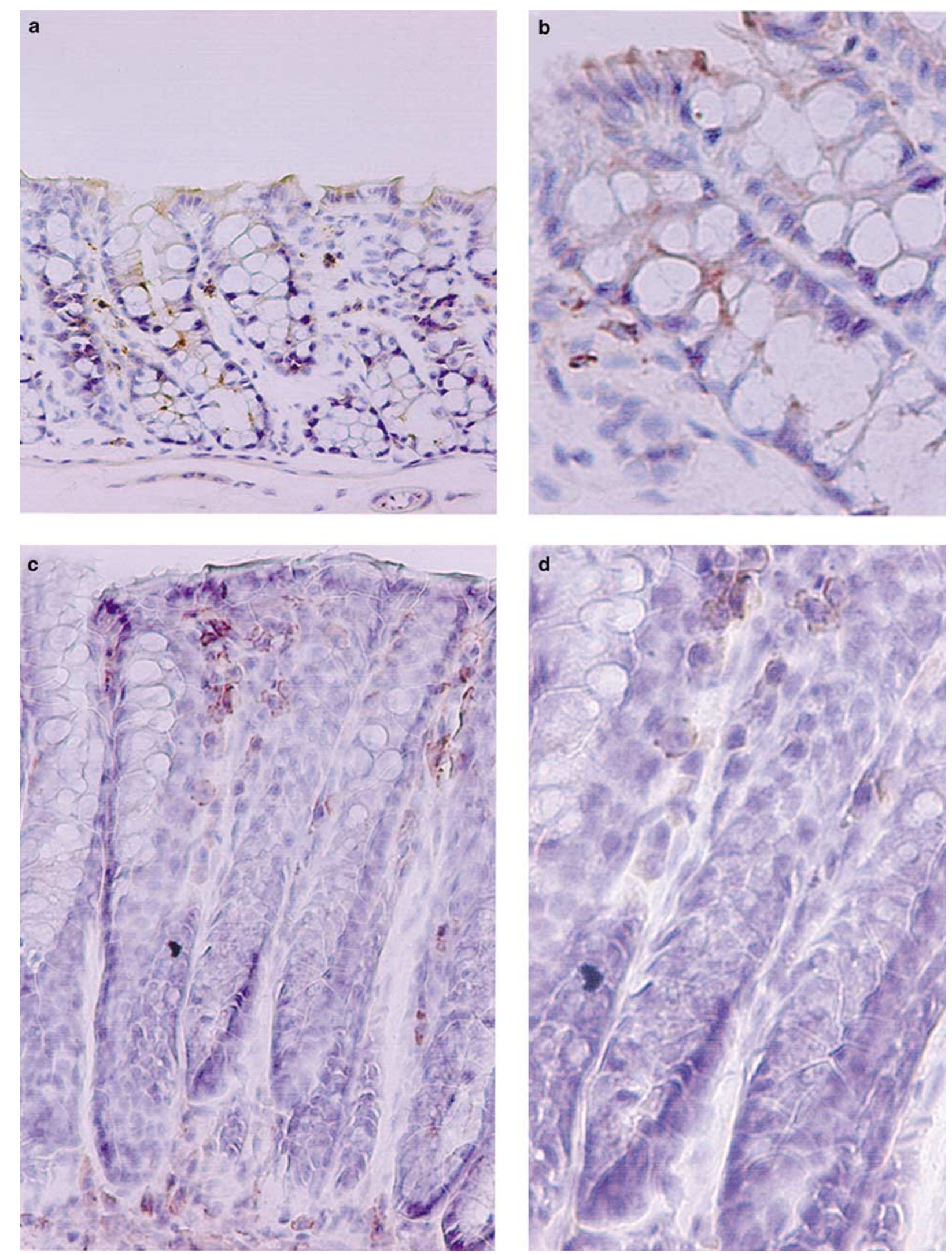

Figure 1 Immunohistochemical analysis. Sections from the colon were incubated with rat anti-mouse IL-12 monoclonal antibody, C15.6, and subsequently incubated with anti-rat immunoglobulin conjugated to HRP. The color reaction was developed with diaminobenzidine. Slides were counterstained with hematoxylin. (a) Colon of IL-12 $440^{+}$mice. $(\times 200)$. (b) Close inspection of the colon of IL-12 p40 ${ }^{+}$mice $(\times 400)$. (c) Colon of IL-12 p40 mice $(\times 200)$. (d) Close inspection of the colon of IL-12 p40 ${ }^{-}$mice $(\times 400)$. 


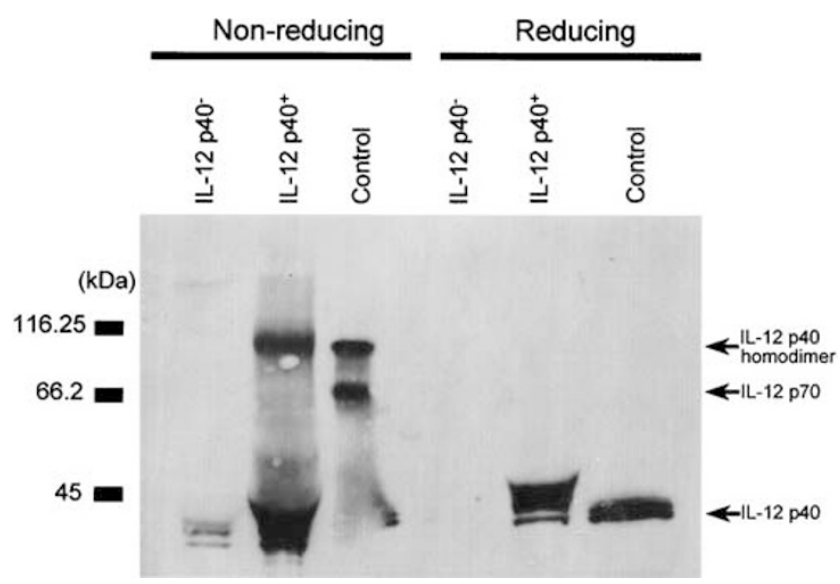

Figure 2 Western blot analysis. IL-12 p40 produced by cultured colon tissue and control protein, which is a mixture of mouse recombinant IL-12 p40 homodimer and recombinant IL-12 heterodimer, were separated by SDS-PAGE (10\%) under reducing or nonreducing conditions, and transferred to a nitrocellulose membrane. Transblots were incubated with a rat anti-mouse IL-12 (p40/p70) monoclonal antibody, C17.8, and then incubated with secondary antibody coupled to horseradish peroxidase.

ELISA showed the massive production of IL-12 p40 in the colon tissue culture of IL-12 $\mathrm{p} 40^{+}$mice (Figure 3a). The IL-12 p40 production in colon tissue of IL-12 $\mathrm{p} 40^{-}$mice was also induced, but the amount was far less than that of IL-12 $\mathrm{p}^{+} 0^{+}$mice. The amount of IL12 measured by ELISA consisted of the IL-12 p40 produced by the epithelium and IL-12 produced by inflammatory cells in the colon. However, we have reported previously the IL-12 p40 expression in the intestine of $\mathrm{T}^{\mathrm{b}}$-IL-12 $\mathrm{p} 40$ transgenic mice that were not crossed $\mathrm{IL}-10^{-/-}$mice was restricted to the epithelial cells. ${ }^{24}$ Thus, the IL-12 p40 in the colonic tissue culture of $\mathrm{IL}-12^{+}$mice measured by ELISA would be produced mainly by the colonic epithelial cells. IL-12 p40 production by mesenteric lymph node cells was induced in IL-12 $\mathrm{p} 40^{+}$mice and IL$12 \mathrm{p} 40^{-}$mice. But no remarkable difference was found between the two groups (Figure 3b).

\section{In contrast to IL-12 $\mathrm{p} 40^{-}$Mice, IL-12 $\mathrm{p} 40^{+}$Mice Gained Weight Normally}

At 8 weeks of age, the IL-12 $\mathrm{p} 40^{-}$mice showed clinical manifestations such as diarrhea, rectal prolapse, and melena, but the IL-12 $\mathrm{p} 40^{+}$mice did not show any manifestations of colitis. In fact, IL-12 p40 mice observed for 24 weeks did not develop histologic evidence of chronic enterocolitis (data not shown). Disease manifestations of the IL-12 ${\mathrm{p} 40^{-}}^{-}$mice appeared nearly at the same age as IL- $10^{-1-}$ mice that were not crossed T3 $3^{\mathrm{b}}$-IL-12 p40 mice under specific pathogen-free conditions of our animal facility. We measured the body weight of the mice to assess the progression of colitis. IL-12 $\mathrm{p} 40^{+}$mice and IL-12 $\mathrm{p} 40^{-}$ mice gained weight similarly until 5 weeks of age. However, the IL-12 ${\mathrm{p} 40^{-}}^{-}$male mice gained less
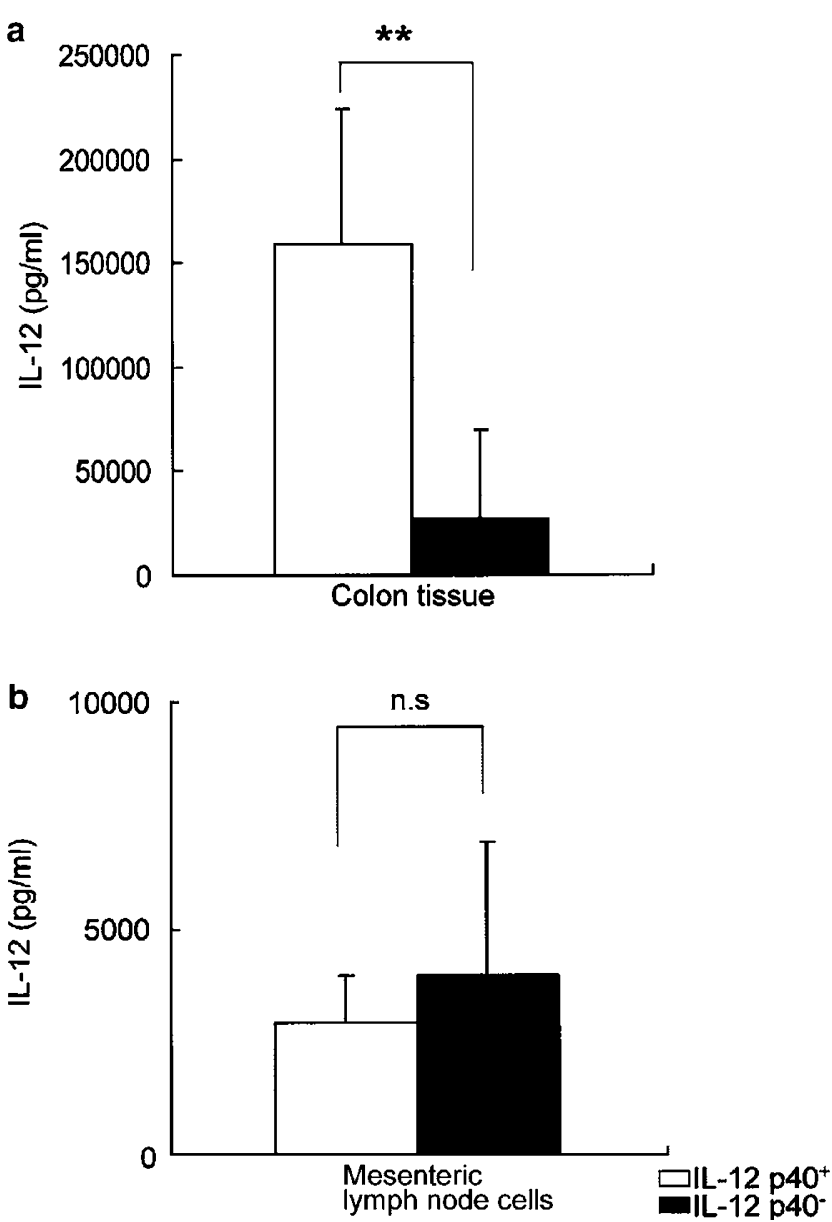

Figure 3 ELISA using IL-12 total ELISA Kit. The manufacturer described that this assay is specific for mouse IL-12 p40 and p70. The measured value of mouse IL-12 homodimer was about twice the true value in this assay. Results are expressed as the mean \pm standard deviation of each group. (a) IL-12 production of mesenteric lymph node cells. n.s. indicates no remarkable difference between $\mathrm{p} 40^{-}$and $\mathrm{p} 40^{+}$mice. (b) IL-12 production of colon tissue culture. ${ }^{*} \mathrm{P}<0.01$ between $\mathrm{IL}-12 \mathrm{p} 40^{+}$mice and IL-12 $\mathrm{p} 40^{-}$mice.

weight than the IL-12 $\mathrm{p} 40^{+}$male mice from 6 weeks of age. At 8 weeks of age, the IL- $12 \mathrm{p} 40^{+}$male mice had gained weight to a similar extent as the wild-type mice (data not shown), but the body weights of the IL-

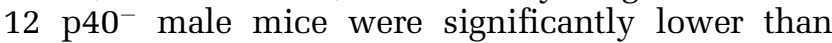
those of the IL-12 $\mathrm{p}^{+} 0^{+}$mice (Figure 4). IL-12 $\mathrm{p} 40^{+}$ female mice also steadily gained weight similarly as the wild type (data not shown) and IL-12 p40- female mice. At 8 weeks of age, there was no statistical difference between the mean body weight of IL-12 $\mathrm{p} 40^{-}$and that of IL-12 $\mathrm{p} 40^{+}$female mice.

\section{Influence of Inflammation on the Colon was Found Macroscopically Only in the IL-12 p40- Mice}

The colon of IL-12 $\mathrm{p} 40^{-}$was edematous and thickened by inflammation with hyperplasia and contained loose stool, while the colon of IL-12 p40 ${ }^{+}$ 


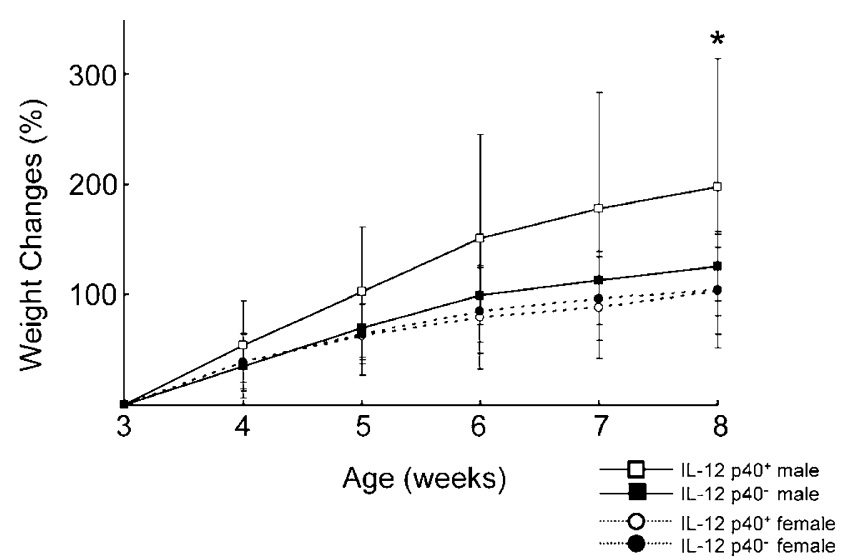

Figure 4 Change in body weights. The ratios of body weight to the weight at 3 weeks of age were plotted. Each group consisted of 10 mice. IL-12 $\mathrm{p}^{+}{ }^{+}$male mice gained weight similarly to the wild type, but IL-12 $\mathrm{p} 40^{-}$male mice gained less weight than IL-12 $\mathrm{p} 40^{+}$mice from 6 weeks of age. The weights of $\mathrm{p} 40^{-}$female mice were similar to those of $\mathrm{p}^{+} 0^{+}$mice during the observation period ${ }^{*} P<0.05$ between IL-12 p40 ${ }^{+}$mice and IL-12 p40 ${ }^{-}$mice.

seemed to be normal macroscopically and the stool in the colon was also normal. The colon length of IL$12 \mathrm{p} 40^{-}$mice was shortened by inflammation, and there was significant difference between IL-12 $\mathrm{p} 40^{+}$ and IL-12 $\mathrm{p}^{-} 0^{-}$mice in the colon length (Figure 5).

\section{Histological Score in IL-12 p40 $^{+}$Mice was Significantly Lower}

We investigated the influence of IL-12 p40 overexpression on intestinal inflammation by histological examination. Histological sections of the colon of IL-12 $\mathrm{p} 40^{+}$mice revealed few findings of inflammation (Figure 6a). Close examination of the sections revealed slight hyperplasia and scant infiltration of inflammatory cells into the mucosa (Figure 6b). Histological sections of the colon of IL- $12 \mathrm{p} 40^{-}$mice revealed infiltration of inflammatory cells into the mucosa and submucosa, severe hyperplasia, depletion of goblet cells (Figure 6c), and mucosal injuries (Figure 6d). The disease score distribution showed that these inflammatory changes could be found in the IL-12 ${\mathrm{p} 40^{-}}^{-}$group even if the mice did not manifest any clinical symptoms. In contrast, the histological observation of IL-12 $\mathrm{p} 40^{+}$mice showed little inflammation of the colon. The mean histological score was significantly lower in the IL-12 $\mathrm{p} 40^{+}$ mice (Table 1). The intestinal inflammation was patchy and the regional disease score revealed that the inflammation was severer in the proximal side of the colon than in the distal side of colon. However, there was no difference in the suppressive effect of IL-12 p40 overexpression among the regions. In addition, there was no statistical difference between male mice and female mice in severity of colitis or any other parameters measured in contrast with body weight changes.

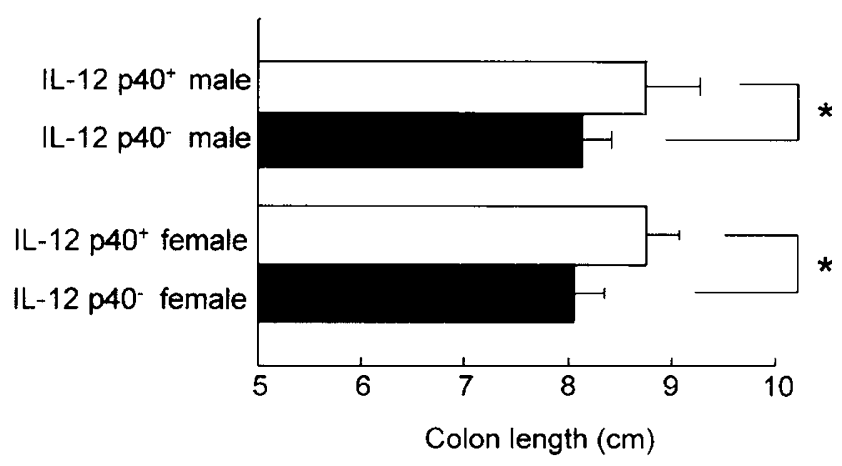

Figure 5 Mean length of the colon. Upper, male mice $(n=8)$. Lower, female mice $(n=7)$. The length of the colon of IL-12 p40mice was significantly shorter than that of $\mathrm{IL}-12 \mathrm{p} 40^{+}$mice. ${ }^{*} P<0.05$ between IL-12 $\mathrm{p} 40^{+}$mice and IL-12 $\mathrm{p} 40^{-}$mice.

\section{Number of Mesenteric Lymph Node Cells and IFN- $\gamma$ Production in $\mathrm{IL}-12 \mathrm{p40}^{+}$Mice were Significantly Reduced}

To investigate the effect of IL-12 p40 overexpression we assessed mesenteric lymph node cell numbers as well as IFN- $\gamma$ production by the mesenteric lymph node cells and colon tissue. The number of lymph node cells was significantly lower in IL-12 $\mathrm{p} 40^{+}$mice than in IL-12 $\mathrm{p}^{-} 0^{-}$mice (Table 2), and it was slightly higher as compared with wild-type mice and T3 ${ }^{\mathrm{b}}$-IL-12 p40 transgenic mice (data not shown). We then performed cell isolation of $\mathrm{CD} 4^{+} \mathrm{T}$ cells. The number of $\mathrm{CD} 4^{+} \mathrm{T}$ cells in IL-12 $\mathrm{p}^{+} 0^{+}$mice was three-fold lower than that in IL-12 $\mathrm{p}^{-} 0^{-}$mice (Table 2). These data may indicate that IL-12 p40 suppressed the expansion of pathogenic T cells. ELISA showed that IFN- $\gamma$ production by the mesenteric lymph node cells was significantly suppressed in $\mathrm{IL}-12 \mathrm{p}^{+} 0^{+}$mice (Figure 7a). The mean concentrations of IFN- $\gamma$ in the culture of mesenteric lymph node cells of IL-12 p40 ${ }^{+}$ mice and IL-12 p40- mice $(n=9)$ were $660 \pm 1539$ and $3341 \pm 2208 \mathrm{pg} / \mathrm{ml}$, respectively. This tendency was also found in the culture of isolated $\mathrm{CD}^{+}{ }^{+} \mathrm{T}$ cells $\left(91.0 \pm 43.6\right.$ and $1930 \pm 794 \mathrm{pg} / \mathrm{ml}$ for IL-12 $\mathrm{p} 40^{+}$mice and IL-12 p40 mice, respectively $(n=5))$ and colon tissue culture $(716 \pm 639$ vs $3442 \pm 1007 \mathrm{pg} / \mathrm{ml}$ for IL-12 $\mathrm{p} 40^{+}$mice and IL-12 $\mathrm{p} 40^{-}$mice, respectively $\left.(n=7)\right)$. Next we assessed the production of other cytokines. IL-4, which is one of the Th2 cytokines that prevent Th1 differentiation, was secreted at very low levels by mesenteric lymph node cells, colon tissue and isolated $\mathrm{CD}^{+}{ }^{+} \mathrm{T}$ cells (Figure $7 \mathrm{~b}$ ). There was no difference in IL-4 secretion between IL-12 $\mathrm{p}^{+} 0^{+}$mice and IL-12 $\mathrm{p} 40^{-}$mice in any of these cultures. The mean concentrations of IL-4 in the cultures of mesenteric lymph node cells were $5.10 \pm 0.272$ vs $11.1 \pm 14.1 \mathrm{pg} /$ $\mathrm{ml}(n=9)$, in the cultures of isolated CD4 ${ }^{+}$T cells IL-4 was lower than detection limit vs $21.4 \pm 36.8 \mathrm{pg} / \mathrm{ml}$ $(n=5)$, and in the colonic tissue cultures it was $6.78 \pm 4.70 \mathrm{pg} / \mathrm{ml}$ vs lower than detection limit $(n=7)$ for IL-12 $\mathrm{p} 40^{+}$mice and IL-12 $\mathrm{p} 40^{-}$mice, respectively. We then investigated TNF- $\alpha$, another proinflammatory mediator (Figure 7c), but there was no significant 

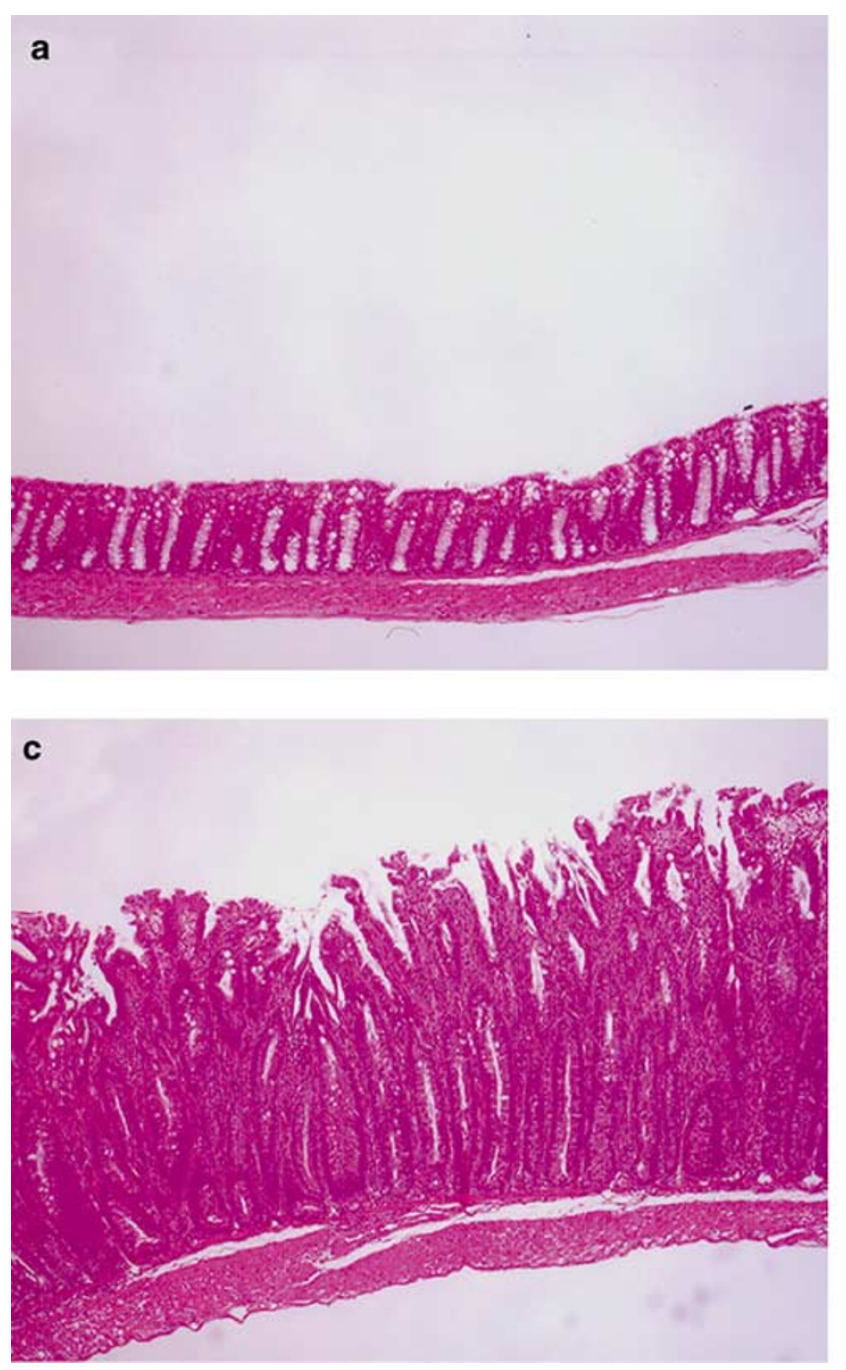
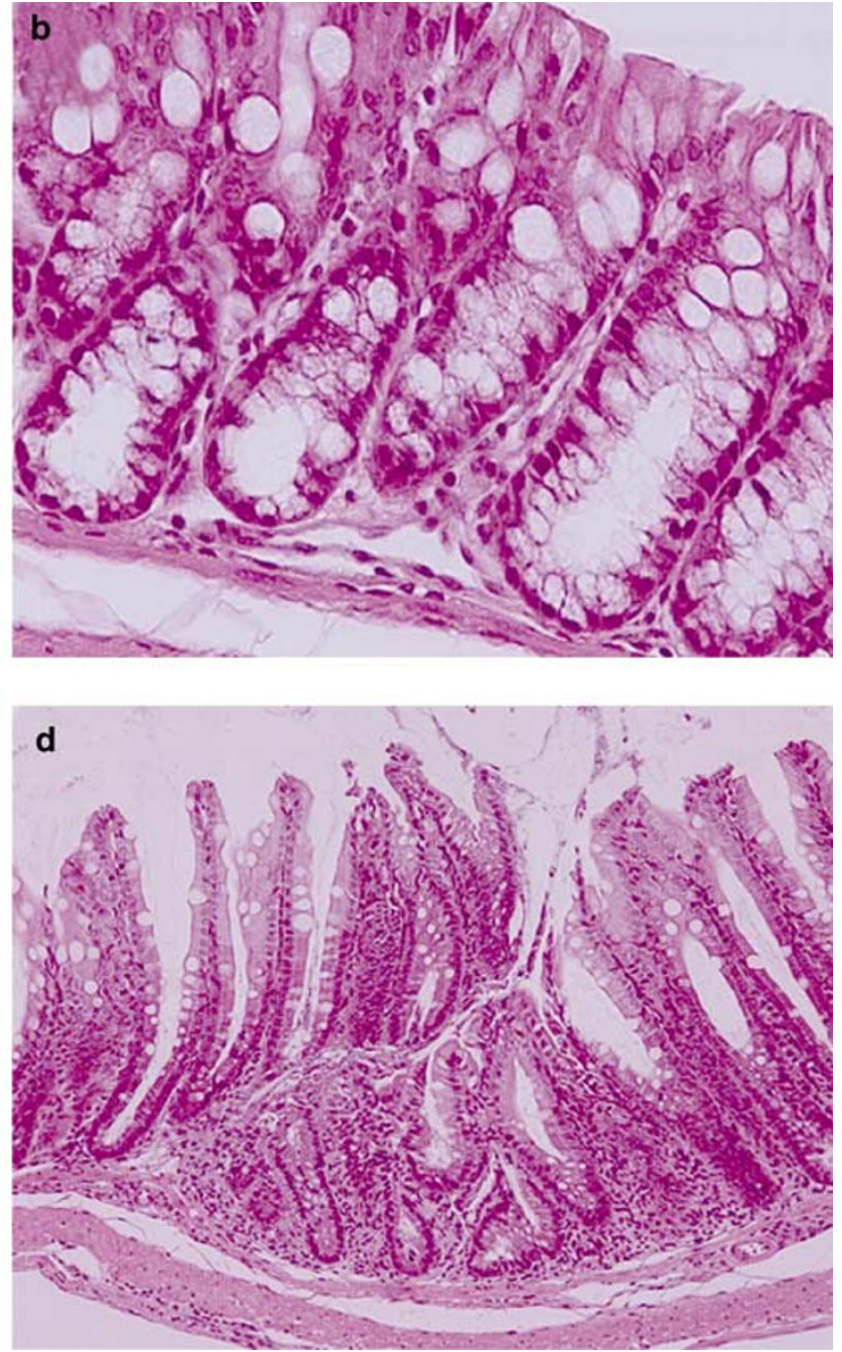

Figure 6 Histological sections of the colon of IL- $12 \mathrm{p} 40^{+}$and IL- $12 \mathrm{p} 40^{-}$mice. Sections were stained by hematoxylin and eosin. (a) Colon of IL-12 p40 ${ }^{+}$mice $(\times 40)$. (b) Higher magnification of the section from IL-12 p40 ${ }^{+}$mice $(\times 200)$. (c) Colon of IL-12 p40 ${ }^{-}$mice $(\times 40)$. (d) Higher magnification of the section from IL-12 $\mathrm{p} 40^{-}$mice $(\times 100)$.

Table 1 Effect of IL-12 p40 overproduction on spontaneous enterocolitis of IL-10 ${ }^{-/-}$mice

\begin{tabular}{|c|c|c|c|c|c|c|c|}
\hline \multirow[t]{2}{*}{ Mice } & \multirow[t]{2}{*}{ Number of mice affected ${ }^{\mathrm{a}}$} & \multicolumn{5}{|c|}{ Disease score distribution ${ }^{\mathrm{b}}$} & \multirow{2}{*}{$\begin{array}{c}\text { Mean disease score } \\
(0-20)\end{array}$} \\
\hline & & $1-4$ & $5-8$ & $9-12$ & $13-16$ & $17-20$ & \\
\hline IL-12 $\mathrm{p} 40^{+}$mice & $0 / 5$ & 3 & 2 & 0 & 0 & 0 & $4.8 \pm 4.7^{* *}$ \\
\hline IL-12 p40 ${ }^{-}$mice & $3 / 5$ & 0 & 1 & 0 & 2 & 2 & $14 \pm 2.2$ \\
\hline
\end{tabular}

${ }^{a}$ Number of mice showing some clinical manifestations such as diarrhea, hematochezia, and rectal prolapse. Each group consisted of five mice. ${ }^{\mathrm{b}}$ Severity of enterocolitis graded semiquantitatively from 0 to 4 .

${ }^{*} P<0.01$ compared with IL-12 $\mathrm{p} 40^{-}$mice.

difference in the production of TNF- $\alpha$ between IL-12 $\mathrm{p} 40^{+}$mice and $\mathrm{IL}-12 \mathrm{p} 40^{-}$mice $(236 \pm 91.6$ and $283 \pm 140 \mathrm{pg} / \mathrm{ml}$, respectively, in the cultures of the mesenteric lymph node cells $(n=9), 335 \pm 145$ vs $289 \pm 146 \mathrm{pg} / \mathrm{ml}$, respectively in the cultures of isolated $\mathrm{CD}^{+}{ }^{+}$T cells $(n=5)$, and $260 \pm 166$ vs $462 \pm 175 \mathrm{pg} / \mathrm{ml}$, respectively in the colonic tissue cultures $(n=7))$.

\section{Discussion}

We demonstrated in the present study that the overexpression of IL-12 p40 in the intestinal epithelium prevented the development of chronic enterocolitis mediated by a Th1 response in IL-10 $10^{-1-}$ mice in all parameters examined. 
Table 2 Number of mesenteric lymph node cells and isolated $\mathrm{CD}^{+} \mathrm{T}$ cells $^{\mathrm{a}}$

\begin{tabular}{lcc}
\hline Mice & $\begin{array}{c}\text { Number of mesenteric } \\
\text { lymph node cells; } \\
\mathrm{n}=10\left(\times 10^{7}\right)\end{array}$ & $\begin{array}{c}\text { Number of isolated } \\
C D 4^{+} \text {T cells; } \mathrm{n}=5 \\
\left(\times 10^{6}\right)\end{array}$ \\
\hline IL-12 ${\mathrm{p} 40^{+} \text {mice }}_{\text {IL-12 } 40^{-} \text {mice }}^{3.0 \pm 1.7^{* *}}$ & $\begin{array}{l}1.2 \pm 0.70^{*} \\
6.3 \pm 2.7\end{array}$ \\
\hline
\end{tabular}

${ }^{\mathrm{a}}$ Values are given as mean \pm standard deviation.

${ }^{*} P<0.05$ and ${ }^{* *} P<0.01$ compared with IL-12 $\mathrm{p} 40^{-}$mice.

IL-12 promotes Th1 differentiation and IFN- $\gamma$ production, ${ }^{15}$ and consequently promotes chronic enterocolitis in IL-10 $0^{-1-}$ mice, especially during the early phase of colitis. ${ }^{31}$ IL-12 p40 has been reported to have the opposite effect on IL-12 heterodimer, ${ }^{21,32}$ especially when in a homodimeric form. ${ }^{21}$ Furthermore, Yoshimoto et $a l^{33}$ previously reported that transgenic mice overexpressing IL-12 p40 regulated by the liver-specific promoter showed reduced Th1 responses. ${ }^{33}$ Thus, the overexpression of IL-12 p40 could suppress the Th1 response and consequently suppress the development of spontaneous chronic enterocolitis in IL-10 $0^{-/-}$mice. Our data are consistent with this scenario insofar as we demonstrated a suppressed Th1 reaction. The numbers of mesenteric lymph node cells were reduced, as were the mesenteric CD ${ }^{+}$T cells in IL- $12 \mathrm{p}^{+} 0^{+}$mice. ELISA revealed the suppression of IFN- $\gamma$ production in the cultures of mesenteric lymph node cells and colon tissue in IL-12 $\mathrm{p}^{+} 0^{+}$mice. In addition, we confirmed the overexpression of IL-12 p40 exclusively in the epithelium of IL-12 $\mathrm{p} 40^{+}$mice by immunohistochemical analysis and ELISA. Western blot analysis revealed that most of IL-12 p40 existed in a homodimeric form.

Many reports have shown that overexpression of p40 suppresses Th1-mediated inflammation. However, there are several reports describing that IL-12 p40 promotes Th1-mediated inflammation. In mice with experimental autoimmune encephalomyelitis, which is Th1 cell-mediated autoimmune demyelinating disease, and human multiple sclerosis, IL-12 p40 was overexpressed in the central nervous system, and that the level of IL-12 p40 was such far higher than that of p35. ${ }^{34-36}$ We think IL-12 p40 could be produced as a damper in such situations. van Boxel-Dezaire et $a l^{34}$ performed the cytokine analysis in patients with relapsing-remitting multiple sclerosis treated with IFN- $\beta 1 \mathrm{~b}$ and described that the baseline levels of IL-12 p35 mRNA were lower in the clinical responders than in the nonresponders. Such a result may indicate that patients with suppressed bioactive IL-12 under the influence of overexpressed IL-12 p40 could be clinical responders. Further studies are required to determine the role of p40 in experimental autoimmune encephalomyelitis and human multiple sclerosis.
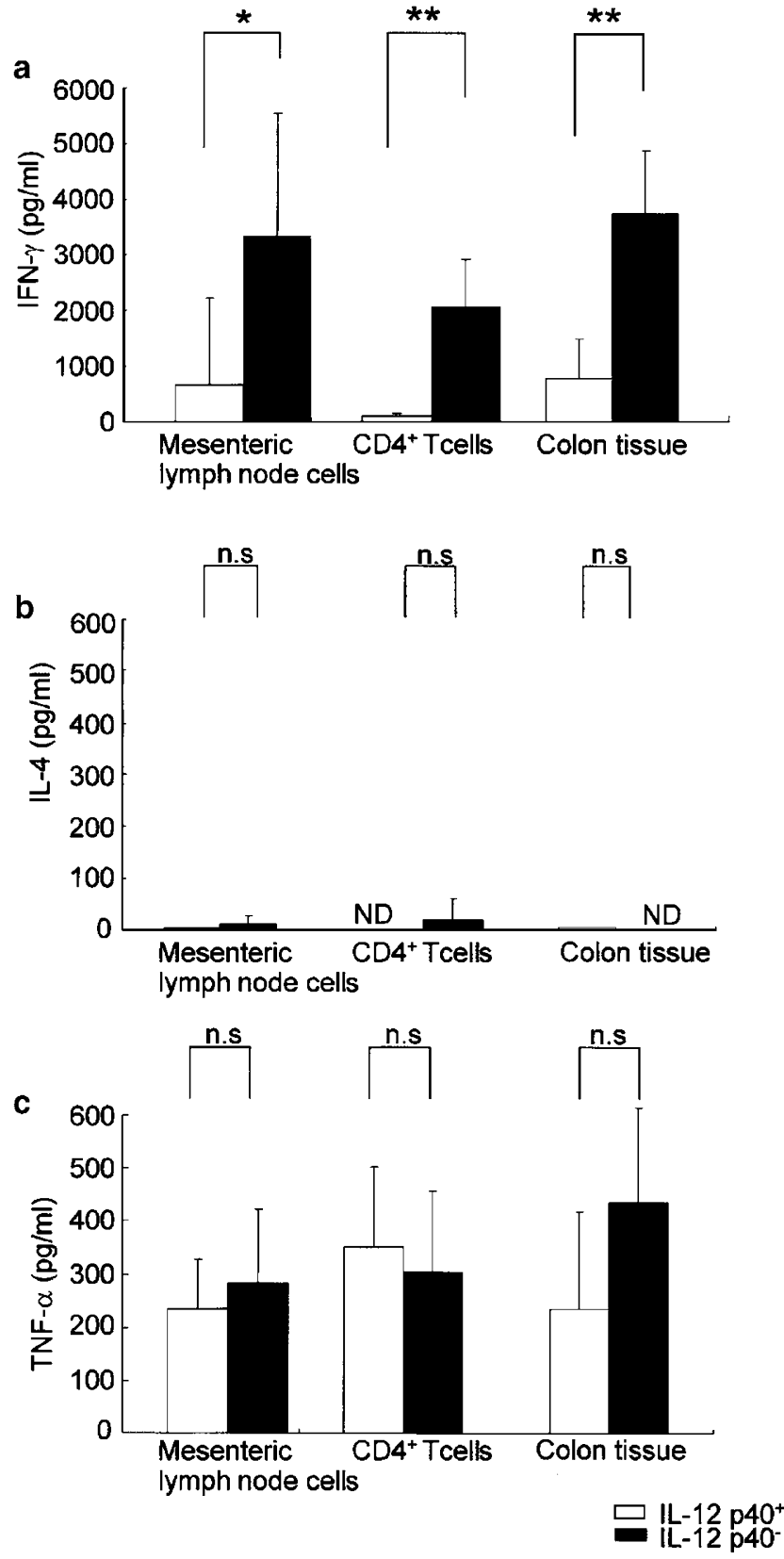

Figure 7 Cytokine analysis. Primary cultures of mesenteric lymph node cells and colon tissue were performed for $24 \mathrm{~h}$. The supernatants were collected for cytokine analysis. Cytokine production was determined by ELISA in culture supernatants from mesenteric lymph node cells $(n=9)$, isolated CD4 ${ }^{+}$T cells and colon tissue $(n=7)$. Data are shown as mean \pm standard deviation $\mathrm{pg} / \mathrm{ml}$ per group. (a) IFN- $\gamma$, (b) IL-4, (c) TNF- $\alpha$. ${ }^{*} P<0.01$ between IL-12 p40 ${ }^{+}$mice and IL-12 p40 ${ }^{-}$mice. n.s. means no significant difference. ND means not detectable.

Recently, IL-23, which is composed of two subunits, p19 and p40, was discovered. ${ }^{37}$ It could be a novel cytokine that promotes the proliferation of memory T cells, and has been reported to possess to some extent a similar function to IL-12. ${ }^{38}$ The $\mathrm{p} 40$ subunit of IL-23 is a protein common to IL-12. Thus, the possibility that the effects of p40 on the IL-23 
pathway prevented the development of colitis in the present study cannot be excluded. For example, IL12 p40 might act a competitor against IL-23 and thereby prevent the development of colitis.

Toxicity from the overexpression of IL-12 p40 was not seen in this study. Some investigators have reported that mice with blocked IL-12 activity were susceptible to infection. Tripp et $a l^{39}$ have reported that anti-IL-12 antibody-treated mice showed increased susceptibility to Listeria burden. Our T3 ${ }^{\mathrm{b}}$-IL12 p40 transgenic mice did not show any abnormalities and their longevity was the same as that of wild-type mice in specific pathogen-free conditions.

In this study, we also demonstrated the potential use of local gene transduction in the intestinal epithelium as a therapy for Crohn's disease. Some investigators have reported the efficacy of gene therapy ${ }^{40-42}$ with adenovirus enemas. The target cells of the adenovirus are ambiguous (epithelium, fibroblast, lymphocyte, etc). Thus, it remains to be shown which kinds of cells in the intestine are the best targets of gene transduction to suppress transluminal colitis. In this study, the overexpression of IL-12 p40 was found exclusively in the epithelial cells of the IL-12 $\mathrm{p} 40^{+}$mice. Although the inflammation of IL-10 $0^{-1-}$ mice was transluminal, the overexpression of IL-12 p40 in the epithelium prevented this transluminal inflammation. This result, therefore, might indicate that local gene transduction in the intestinal epithelium alone could be a potent therapy (including the prevention of relapse) for Crohn's disease.

The clinical benefits of cytokine therapies such as with an anti-TNF- $\alpha$ agent have been reported, ${ }^{43}$ and some investigators have reported the efficacy of antiIL-12 antibodies in preventing the development of the intestinal inflammation mediated by a Th1 response. ${ }^{12,17,29,44}$ In contrast, it has been anticipated that the use of antibody agent could induce the production of an anti-drug antibody such as an antiidiotype antibody. We think that IL-12 p40 would not induce the synthesis of an unwelcome antibody because it exists naturally in vivo.

In conclusion, the present data demonstrated that the overexpression of IL-12 p40 by the T3 ${ }^{\mathrm{b}}$-IL-12 p40 transgene in the gastrointestinal tract can suppress the production of IFN $-\gamma$ by CD $4^{+}$Th1 cells, which mediate intestinal inflammation. These data suggest a potential clinical application of IL-12 p40 for IBD. Furthermore, we also demonstrated the possibility of employing local gene transduction in the intestinal epithelium as a therapy for Crohn's disease.

\section{References}

1 Podolsky DK. Inflammatory bowel disease (1). N Engl J Med 1991;325:928-937.

2 Fiocchi C. Inflammatory bowel disease: etiology and pathogenesis. Gastroenterology 1998;115:182-205.
3 Podolsky DK. Inflammatory bowel disease. N Engl J Med 2002;347:417-429.

4 Ehrhardt RO, Ludviksson BR, Gray B, et al. Induction and prevention of colonic inflammation in IL-2deficient mice. J Immunol 1997;158:566-573.

$5 \mathrm{Ma} \mathrm{A}$, Datta M, Margosian E, et al. T cells, but not $\mathrm{B}$ cells, are required for bowel inflammation in interleukin 2-deficient mice. J Exp Med 1995;182: 1567-1572.

6 Kobayashi M, Kweon MN, Kuwata H, et al. Toll-like receptor-dependent production of IL-12 p40 causes chronic enterocolitis in myeloid cell-specific Stat3deficient mice. J Clin Invest 2003;111:1297-1308.

7 Watanabe M, Ueno Y, Yajima T, et al. Interleukin 7 transgenic mice develop chronic colitis with decreased interleukin 7 protein accumulation in the colonic mucosa. J Exp Med 1998;187:389-402.

8 Kontoyiannis D, Pasparakis M, Pizarro TT, et al. Impaired on/off regulation of TNF biosynthesis in mice lacking TNF AU- rich elements: implications for joint and gut-associated immunopathologies. Immunity 1999;10:387-398.

9 Kontoyiannis D, Boulougouris G, Manoloukos M, et al. Genetic dissection of the cellular pathways and signaling mechanisms in modeled tumor necrosis factor-induced Crohn's-like inflammatory bowel disease. J Exp Med 2002;196:1563-1574.

10 Matsumoto S, Okabe Y, Setoyama H, et al. Inflammatory bowel disease-like enteritis and caecitis in a senescence accelerated mouse P1/Yit strain. Gut 1998;43:71-78.

11 Kosiewicz MM, Nast CC, Krishnan A, et al. Th1-type responses mediate spontaneous ileitis in a novel murine model of Crohn's disease. J Clin Invest 2001; 107:695-702.

12 Neurath MF, Fuss I, Kelsall BL, et al. Antibodies to interleukin 12 abrogate established experimental colitis in mice. J Exp Med 1995;182:1281-1290.

13 Powrie F, Leach MW, Mauze S, et al. Phenotypically distinct subsets of CD4+ T cells induce or protect from chronic intestinal inflammation in C. B-17 scid mice. Int Immunol 1993;5:1461-1471.

14 Reimann J, Rudolphi A, Claesson MH. Reconstitution of SCID mice with low numbers of CD4+ TCR alpha beta + T cells. Res Immunol 1994;145:332-337.

15 Trembleau S, Germann T, Gately MK, et al. The role of IL-12 in the induction of organ-specific autoimmune diseases. Immunol Today 1995;16:383-386.

16 Gately MK, Renzetti LM, Magram J, et al. The interleukin-12/interleukin-12-receptor system: role in normal and pathologic immune responses. Annu Rev Immunol 1998;16:495-521.

17 Liu Z, Geboes K, Heremans H, et al. Role of interleukin12 in the induction of mucosal inflammation and abrogation of regulatory $\mathrm{T}$ cell function in chronic experimental colitis. Eur J Immunol 2001;31:1550-1560.

18 Monteleone G, Biancone L, Marasco R, et al. Interleukin 12 is expressed and actively released by Crohn's disease intestinal lamina propria mononuclear cells. Gastroenterology 1997;112:1169-1178.

19 Parronchi P, Romagnani P, Annunziato F, et al. Type 1 T-helper cell predominance and interleukin-12 expression in the gut of patients with Crohn's disease. Am J Pathol 1997;150:823-832.

20 Schmidt C, Marth T, Wittig BM, et al. Interleukin-12 antagonists as new therapeutic agents in inflammatory bowel disease. Pathobiology 2002;70:177-183. 
21 Gillessen S, Carvajal D, Ling P, et al. Mouse interleukin-12 (IL-12) p40 homodimer: a potent IL-12 antagonist. Eur J Immunol 1995;25:200-206.

22 Heinzel FP, Ahmed F, Hujer AM, et al. Immunoregulation of murine leishmaniasis by interleukin-12. Res Immunol 1995;146:575-581.

23 Tsujimura K, Obata Y, Matsudaira Y, et al. The binding of thymus leukemia (TL) antigen tetramers to normal intestinal intraepithelial lymphocytes and thymocytes. J Immunol 2001;167:759-764.

24 Aihara H, Hiwatashi N, Kumagai S, et al. The T3(b) gene promoter directs intestinal epithelial cell-specific expression in transgenic mice. FEBS Lett 1999; 463:185-188.

25 Kuhn R, Lohler J, Rennick D, et al. Interleukin-10deficient mice develop chronic enterocolitis. Cell 1993;75:263-274.

26 Davidson NJ, Leach MW, Fort MM, et al. T helper cell 1-type CD4+ T cells, but not B cells, mediate colitis in interleukin 10-deficient mice. J Exp Med 1996; 184:241-251.

27 Berg DJ, Davidson N, Kuhn R, et al. Enterocolitis and colon cancer in interleukin-10-deficient mice are associated with aberrant cytokine production and CD4(+) TH1-like responses. J Clin Invest 1996; 98:1010-1020.

28 Bristol IJ, Farmer MA, Cong Y, et al. Heritable susceptibility for colitis in mice induced by IL-10 deficiency. Inflamm Bowel Dis 2000;6:290-302.

29 Davidson NJ, Hudak SA, Lesley RE, et al. IL-12, but not IFN-gamma, plays a major role in sustaining the chronic phase of colitis in IL-10-deficient mice. J Immunol 1998;161:3143-3149.

30 Dieleman LA, Ridwan BU, Tennyson GS, et al. Dextran sulfate sodium-induced colitis occurs in severe combined immunodeficient mice. Gastroenterology 1994; 107:1643-1652.

31 Spencer DM, Veldman GM, Banerjee S, et al. Distinct inflammatory mechanisms mediate early versus late colitis in mice. Gastroenterology 2002;122:94-105.

32 Camoglio L, Juffermans NP, Peppelenbosch M, et al. Contrasting roles of IL-12 p40 and IL-12 p35 in the development of hapten-induced colitis. Eur J Immunol 2002;32:261-269.
33 Yoshimoto $\mathrm{T}$, Wang CR, Yoneto $\mathrm{T}$, et al. Reduced $\mathrm{T}$ helper 1 responses in IL-12 p40 transgenic mice. J Immunol 1998;160:588-594.

34 van Boxel-Dezaire AH, Hoff SC, van Ooste BW, et al. Decreased interleukin-10 and increased interleukin-12 p40 mRNA are associated with disease activity and characterize different disease stages in multiple sclerosis. Ann Neurol 1999;45:695-703.

35 Fassbender K, Ragoschke A, Rossol S, et al. Increased release of interleukin-12p40 in MS: association with intracerebral inflammation. Neurology 1998;51:753-758.

36 Bright JJ, Musuro BF, Du C, et al. Expression of IL-12 in CNS and lymphoid organs of mice with experimental allergic encephalitis. J Neuroimmunol 1998;82:22-30.

37 Oppmann B, Lesley R, Blom B, et al. Novel p19 protein engages IL-12 p40 to form a cytokine, IL-23, with biological activities similar as well as distinct from IL-12. Immunity 2000;13:715-725.

38 Belladonna ML, Renauld JC, Bianchi R, et al. IL-23 and IL-12 have overlapping, but distinct, effects on murine dendritic cells. J Immunol 2002;168:5448-5454.

39 Tripp CS, Gately MK, Hakimi J, et al. Neutralization of IL-12 decreases resistance to Listeria in SCID and C.B-17 mice. Reversal by IFN-gamma. J Immunol 1994; 152:1883-1887.

40 Lindsay J, Van Montfrans C, Brennan F, et al. IL-10 gene therapy prevents TNBS-induced colitis. Gene Therapy 2002;9:1715-1721.

41 Lindsay JO, Ciesielski CJ, Scheinin T, et al. Local delivery of adenoviral vectors encoding murine interleukin 10 induces colonic interleukin 10 production and is therapeutic for murine colitis. Gut 2003;52:981-987.

42 Wirtz S, Becker C, Blumberg R, et al. Treatment of $\mathrm{T}$ cell-dependent experimental colitis in SCID mice by local administration of an adenovirus expressing IL-18 antisense mRNA. J Immunol 2002;168:411-420.

43 van Dullemen HM, van Deventer SJ, Hommes DW, et al. Treatment of Crohn's disease with anti-tumor necrosis factor chimeric monoclonal antibody (cA2). Gastroenterology 1995;109:129-135.

44 Fuss IJ, Marth T, Neurath MF, et al. Anti-interleukin 12 treatment regulates apoptosis of Th1 T cells in experimental colitis in mice. Gastroenterology 1999; 117:1078-1088. 